\begin{tabular}{|l|l|l|l|l|l|}
\hline J. Tek. Ling & Vol. 12 & No. 2 & Hal. 121 - 129 & Jakarta, Mei 2011 & ISSN 1441-318X \\
\hline
\end{tabular}

\title{
PERBAIKAN KUALITAS AIR BAKU PERUSAHAAN AIR MINUM (PAM) DENGAN BIOFILTRASI
}

\author{
Rudi Nugroho dan Nusa Idaman Said \\ Pusat Teknologi Lingkungan, Badan Pengkajian dan Penerapan Teknologi \\ (BPPT), JL MH. Thamri No 8 Jakarta Pusat
}

\begin{abstract}
A study to improve the raw water quality at Taman Kota Drinking Water Company was conducted by using pilot plant of biofiltration system. The pilot plant was run by pumping the raw water from river to the reactor continuously with various Hydraulic Retention Time. Samples of raw water and treated water were taken daily and analyzed for $\mathrm{pH}$, Total Suspended Solid (TSS), Organic matter, Ammonia nitrogen and Detergent (MBAS). The results showed that performance of biofiltration system decreaed due to shortening Hydraulic Retention Times (HRT). The longer HRT caused bigger volume of biofiltration tank. Therefore, this study suggests that the optimum Hydraulics retention time is $1 \mathrm{hr}$. In this HRT, the treated water quality were $7.2 \mathrm{for} \mathrm{pH}, 40 \mathrm{mg} / \mathrm{l}$ for TSS, $10,7 \mathrm{mg} / \mathrm{l}$ for organic matter, $0.35 \mathrm{mg} / \mathrm{l}$ for ammonia nitrogen and $0.1 \mathrm{mg} / \mathrm{l}$ for MBAS. These results comply with the Regulation No. 582 year 1995 for raw drinking water quality (class B).
\end{abstract}

Key Words: Biofiltration, Raw Water Quality, Drinking Water

\section{PENDAHULUAN}

Air merupakan kebutuhan yang sangat pokok bagi manusia, terutama untuk memasak dan minum. Dengan pesatnya perkembangan penduduk maka kebutuhan air bersih untuk masyarakat juga semakin bertambah besar. Dampak dari perkembangan penduduk yang pesat, membawa akibat pada buruknya kualitas air sungai sebagai air baku air minum. Akibat pencemaran dari limbah domestik. Dengan semakin buruknya kualitas air baku untuk air minum, maka disamping biaya produksinya air di Instalasi Pengolahan Air (IPA) membesar, hasil olahannya pun sering kurang baik.

Salah satu permasalahan yang dihadapi oleh PAM di DKI Jakarta khususnya yang dihadapi oleh PT. PAM LYONAISE JAYA (PALYJA) adalah masalah kualitas air baku yang buruk akibat ari pencemaran limbah domestik ke dalam sungai, terutama untuk Instalasi Taman Kota Jakarta Barat. Dari hasil pemantauan yang dilakukan terhadap air baku (intake water) di instalasi Perusahaan Air Minum (PAM) Taman Kota tersebut pada bulan September 2007 oleh Tody1) menunjukkan bahwa konsentrasi amonia nitrogen bervariasi antara 2,44 $\mathrm{mg} / \mathrm{l}$ hingga mencapai $5,24 \mathrm{mg} / \mathrm{l}$, dimana nilai konsentrasi tersebut telah melampaui ambang batas peruntukkan air baku air minum yakni sebesar $1 \mathrm{mg} / \mathrm{l}$ menurut Kep. Gub. DKI Jakarta No. 582 th $1995,{ }^{2)}$ sehingga dengan IPA yang ada tidak mampu 
mengolah air tersebut menjadi air minum yang memenuhi standar. Dampaknya IPA Taman Kota dari tahun 2008 sampai sekarang tidak dioperasikan.

Untuk mengatasi tingginya amonia nitrogen, PAM di Indonesia khususnya PAM di DKI Jakarta menggunakan senyawa khlor (gas khlor atau kalsium hipoklorit) untuk proses desinfeksi dan untuk menghilangkan amonia nitrogen serta senyawa Besi dan Mangan.. Dengan semakin besarnya konsentrasi senyawa amoniak dalam air baku, maka amoniak akan bereaksi dengan khlor menjadi khloramine yang daya desinfeksinya lebih lemah. Dengan demikian, tingginya amoniak ini akan mengakibatkan konsumsi khlor akan menjadi lebih besar sehingga biaya operasi menjadi lebih tinggi.

Selain itu dengan semakin besarnya konsentrasi senyawa khlor yang digunakan, maka hasil samping yang dihasilkan seperti senyawa trihalometan dan khlorophenol juga semakin besar. Senyawa-senyawa tersebut dapat mengakibatkan penyakit kanker (carcinogen). Oleh karena itu zat pencemar amoniak harus dihilangkan.

Saat ini, untuk menghilangkan polutan organik, deterjen, bau dan polutan mikro lainnya di dalam air minum, PAM biasanya menggunakan proses pengolahan dengan proses adsorbsi Karbon Aktif Bubuk yang harganya cukup mahal, dilanjutkan dengan pengolahan secara fisika yaitu dengan proses koagulasi, flokulasi, sedimentasi serta desinfeksi dengan khlor. Bila konsentrasi polutan tersebut di air baku tinggi, maka pengolahan air di IPA dengan metode ini akan tidak ekonomis.

Untuk mengurangi kadar senyawa organik, deterjen dan amoniak di dalam air baku air minum maka air sungai harus diolah terlebih dahulu melalui suatu pengolahan pendahuluan sebelum masuk ke unit pengolahan. Salah satu alternatif yakni menggunakan proses biologis dengan sistem biofilter tercelup yang diisi dengan media penyangga dari bahan plastik tipe sarang tawon atau yang dinamakan biofiltrasi.
Saat ini IPA Taman Kota tidak dioperasikan karena kualitas air baku yang diolah sangat buruk, karena tercemar limbah domestik, sehingga tidak memungkinkan untuk diolah menjadi air bersih dengan fasilitas yang saat ini ada di Taman Kota. Untuk menambah peralatan pre-treatment konvensional guna melengkapi fasilitas yang ada juga tidak mungkin, karena sempitnya lahan yang tersedia.

Tujuan studi ini adalah untuk mengkaji perbaikan kualitas air baku dengan menggunakan proses biofiltrasi sebagai pre-treatment sehingga kualitas air baku PAM Taman Kota layak digunakan sebagai air baku air minum. Target kualitas air hasil olahan biofiltrasi ini adalah memenuhi standar air baku golongan B pada SK Gub. DKI No 582 tahun 1995.

\section{TINJAUAN TEORI}

Salah satu problem atau masalah yang sering dijumpai pada air minum di dunia akhir-akhir ini yakni timbulnya senyawa yang dinamakan Trihalomethanes atau disingkat THMs, sebagai akibat samping dari proses desinfeksi dengan gas khlor atau senyawa hipokhlorit.

Polutan yang ada di sungai oleh karena pencemaran limbah domestik diataranya adalah deterjen, Amonia, Organik, Besi dan lain sebagainya. Menurut Garno ${ }^{3)}$ seperti yang dikutip dari Sawyer \& Mc.Carty ${ }^{4}$ bahwa deterjen atau surfaktan adalah senyawa yang molekulnya mempunyai struktur gugus tertentu yang menyebabkan senyawa tersebut mempunyai sifat-sifat deterjen misalnya sifat dapat menimbulkan busa. Deterjen mempunyai kemampuan untuk menghilangkan kotoran pada pakaian, sehingga banyak digunakan sebagai bahan pembersih. Untuk mengaktifkan sifat pembersinnya itu, deterjen dilengkapi zat kimia yang mampu mengurangi tegangan permukaan air, sehingga dapat menimbulkan busa.

Permasalahan yang timbul kemudian adalah karena zat pengaktif tersebut yang 
disebut sebagai surfactant agents atau detergen misalnya ABS (Alkyl Benzene Sulfonate), sulit diuraikan secara biologis (non-biodegradable). ABS ini ternyata masih banyak digunakan sebagai bahan baku deterjen di Indonesia dan membawa dampak dari pemakaiannya. Menurut Ainsworth, ${ }^{5)}$ detergen akan dapat membentuk lapisan film pada permukaan badan air yang menyebabkan perpindahan oksigen dari udara ke air terganggu. Bila konsentrasi deterjen melebihi konsentrasi 3 ppm akan menyebabkan terbentuknya busa yang stabil. Selain itu deterjen akan mudah mengikat polyphosphate yang menyebabkan kandungan nutrien di badan air meningkat yang menyebabkan eutrophikasi.

Amonia dan organik dapat dihilangkan dari air baku air minum dengan proses biologis. Pengolahan air secara biologis merupakan suatu proses penguraian bahanbahan pencemar, baik yang terlarut maupun yang tidak terlarut menjadi bentuk yang lain berupa gas atau padatan. ${ }^{6)}$ Hasil dari transformasi tersebut dipengaruhi oleh kondisi lingkungan pada saat proses berlangsung yaitu kondisi aerobik dan anaerobik.

Proses pengolahan biologis secara aerobik merupakan suatu proses yang membutuhkan oksigen untuk menunjang berlangsungnya proses metabolisme biokimia oleh bakteri dalam penguraian bahan-bahan organik menjadi bentuk yang lebih sederhana yaitu $\mathrm{CO}_{2}, \mathrm{H}_{2} \mathrm{O}$, senyawa-senyawa oksida seperti nitrat, sulfat, phosphat dan terbentuknya massa sel yang baru ${ }^{7}$.

Pada pengolahan secara biologis, pertumbuhan mikroorganisme dapat dilakukan secara melekat pada permukaan media penyangga (attached growth), yakni suatu proses pengolahan dimana senyawasenyawa organik atau senyawa-senyawa lainnya yang terdapat dalam air diuraikan oleh mikroorganisme yang melekat pada permukaan media penyangga menjadi senyawa yang lebih sederhana serta membentuk biomasa atau sel-sel baru.

Zat Organik dapat disisihkan secara biologi tergantung dari jumlah oksigen terlarut, jenis mikroorganisme dan jumlah zat pengurai. Adanya $\mathrm{O}_{2}$ menyebabkan proses oksidasi aerob dapat berlangsung, yakni bahan - bahan organik akan diubah menjadi $\mathrm{CO}_{2}$ dan $\mathrm{H}_{2} \mathrm{O}$ yang relatif stabil dan sisanya akan disintesis menjadi mikroba baru. Secara umum dapat dilihat pada persamaan :

$$
\begin{aligned}
& \text { Mikroba } \\
& \text { Senyawa Organik }+\mathrm{O}_{2} \stackrel{------->\mathrm{CO}_{2}}{ }+ \\
& \mathrm{H}_{2} \mathrm{O}+\text { Sel-sel baru }+ \text { Energi }
\end{aligned}
$$

Di dalam proses biofiltrasi, senyawa amoniak akan diubah menjadi nitrit, kemudian senyawa nitrit akan diubah menjadi nitrat. Mekanisme proses penguraian senyawa amoniak pada lapisan biofilm secara sederhana dapat diilustrasikan seperti pada Gambar 1.

Lapisan terluar media penyangga biofiltrasi adalah lapisan tipis zona aerobik, senyawa amoniak dioksidasi dan diubah ke dalam bentuk nitrit. Sebagian senyawa nitrit ada yang diubah menjadi gas dinitrogen oksida $\left(\mathrm{N}_{2} \mathrm{O}\right)$ dan ada yang diubah menjadi

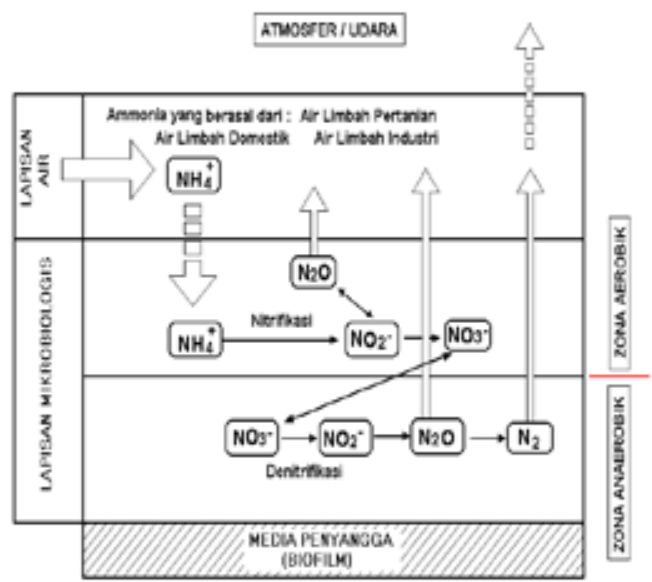

Gambar 1 : Ilustrasi dari mekanisme proses penguraian amonia di dalam biofilm 
Semakin lama, lapisan biofilm yang tumbuh pada media penyangga tersebut semakin tebal sehingga oksigen tidak dapat masuk ke dalam lapisan biofilm yang mengakibatkan terbentuknya zona anaerobik. Pada zona anaerobik ini, senyawa nitrat yang terbentuk diubah ke dalam bentuk nitrit yang kemudian dilepaskan menjadi gas nitrogen $\left(\mathrm{N}_{2}\right)$. Proses demikian tersebut dinamakan proses denitrifikasi.

Proses nitrifikasi menurut Gardy \& Lim $^{8)}$ didefinisikan sebagai konversi amonia nitrogen $\left(\mathrm{NH}_{4}-\mathrm{N}\right)$ menjadi nitrit $\left(\mathrm{NO}_{2}-\mathrm{N}\right)$ yang kemudian menjadi nitrat $\left(\mathrm{NO}_{3}-\mathrm{N}\right)$ yang dilakukan oleh bakteri autotropik dan heterotropik. Proses nitrifikasi ini berlangsung dalam dua tahap yaitu tahap nitritasi yakni oksidasi ion ammonium $\left(\mathrm{NH}_{4}^{+}\right)$menjadi ion nitrit $\left(\mathrm{NO}_{2}^{-}\right)$yang dilaksanakan oleh bakteri nitrosomonas dan tahap nitrasi yakni oksidasi ion nitrit menjadi ion nitrat $\left(\mathrm{NO}_{3}^{-}\right)$yang dilaksanakan oleh bakteri nitrobacter.

Bakteri nitrosomonas dan nitrobacter ini dikenal sebagai bakteri autotropik yaitu bakteri yang dapat tumbuh dan berkembang biak dengan karbon dan nitrogen dari bahan-bahan anorganik dengan sendirinya. Bakteri ini menggunakan energi dari proses nitrifikasi untuk membentuk sel sintesa yang baru. Walaupun bakteri nitrifikasi autotropik keberadaannya di alam lebih banyak, proses nitrifikasi dapat juga dilakukan oleh bakteri jenis heterotropik (Arthobacter) dan jamur (Aspergillus) ${ }^{9)}$. Bakteri heterotropik merupakan bakteri yang membutuhkan bahan-bahan organik untuk membangun protoplasma.

Pada proses pengolahan senyawa $\mathrm{NH}_{4}-\mathrm{N}$ secara biologis kebutuhan oksigen $\left(\mathrm{O}_{2}\right)$ cukup besar, sehingga kebutuhan $\mathrm{O}_{2}$ yang tinggi dapat dipenuhi dengan cara memperbesar transfer $\mathrm{O}_{2}$ ke dalam bioreaktor instalasi pengolahan. Pada bioreaktor ini, transfer $\mathrm{O}_{2}$ yang besar dapat diperoleh dengan cara menginjeksikan udara ke dalamnya. Dengan adanya injeksi udara diharapkan kontak antara gelembung udara dan air dapat terjadi.

\section{METODOLOGI PENELITIAN}

Penelitian dilakukan dalam bulan Desember 2009 sampai dengan bulan April 2010 di Intake air baku PAM Taman Kota Jakarta Barat dengan menggunakan reaktor biofiltrasi berskala pilot plant. Reaktor ini mempunyai ukuran panjang $3,4 \mathrm{~m}$, lebar $1,5 \mathrm{~m}$, dan kedalaman air efektif $2,0 \mathrm{~m}$. Total volume reaktor biofilter $10,2 \mathrm{~m}^{3}$, dibuat dari bahan fiber glass seperti yang ditunjukkan pada Gambar 2.

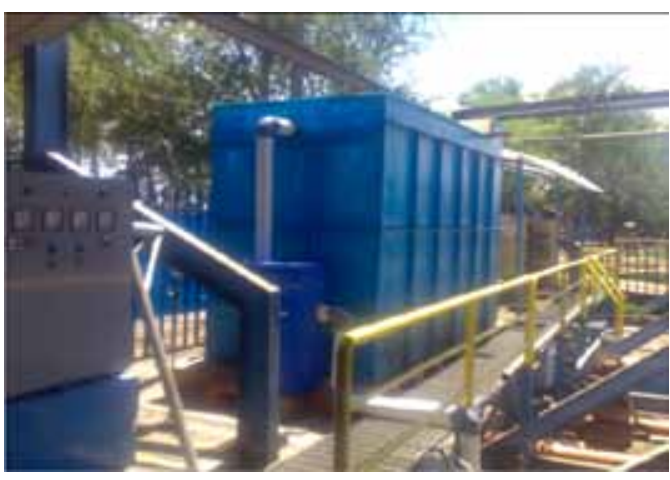

Gambar 2. Pilot plant biofiltrasi di Intake Taman Kota

Bahan yang digunakan adalah bahan kimia analisa berupa reagent Hach Nitraver, Asam Sulfat, Chloroform, Kalium Permanganat dan lain sebagainya.

Variable berubah dalam penelitian yakni waktu tinggal hidrolis atau Hydraulic Retention Time (HRT). Waktu tinggal hidrolis (jam) dihitung dengan persamaan:

$$
\text { HRT }=\frac{\text { VolumeTangkiBiofiltrasi }\left(\mathrm{m}^{3}\right)}{\text { debit air ke tangki biofiltrasi }\left(\mathrm{m}^{3} / \mathrm{jam}\right)}
$$

Untuk menentukan HRT, yang perlu dilakukan adalah dengan mengatur debit air yang masuk ke tangki. Caranya dengan mengatur bukaan valve yang ada di pipa aliran inlet. Target penelitian ini adalah dengan waktu tinggal maksimal 1 jam dapat diperoleh kualitas air baku yang sudah memenuhi persyaratan. 
Gambar 3 memperlihatkan skema penelitian biofiltrasi. Unit biofiltrasi ini terdiri dari bak bak biofilter yang berisi media penyangga dan bak pengendapan akhir. Reaktor biofiltrasi ini dilengkapi dengan pipa inlet dan pipa outlet yang terletak pada kedua sisi reaktor. Pada bagian bawah reaktor terdapat ruang lumpur yang berfungsi sebagai tempat pengendapan yang dapat digunakan untuk mengeluarkan lumpur yang mengendap.

Pengaliran air selama proses penelitian dilakukan secara terus-menerus (continues flow). Pemberian oksigen dilakukan menggunakan blower udara yang diinjeksikan ke dalam reaktor melalui suatu difuser. Pada saat awal biofiltrasi beroperasi, ditambahkan starbio yang merupakan enzym untuk mempercepat perkembang biakan mikroorganisma.

Media penyangga yang dipergunakan adalah sarang tawon (cross flow) yang terbuat dari plastik (Gambar 4). Ukuran modul tiap media adalah $30 \times 25 \times 30 \mathrm{~cm}$, dengan luas spesifik permukaan $220 \mathrm{~m}^{2} / \mathrm{m}^{3}$. Ketinggian media dalam reaktor biofltrasi adalah 1,5 m dengan total volume 3,375 $\mathrm{m}^{3}$. Perbandingan volume media terhadap volume efektif reaktor biofilter ditetapkan 0,4 , mengacu kepada proses pengolahan awal (pretreatment) air minum secara biologis yang telah ada yakni Mishima Water Purification Plant, Osaka, Japan. ${ }^{10)}$

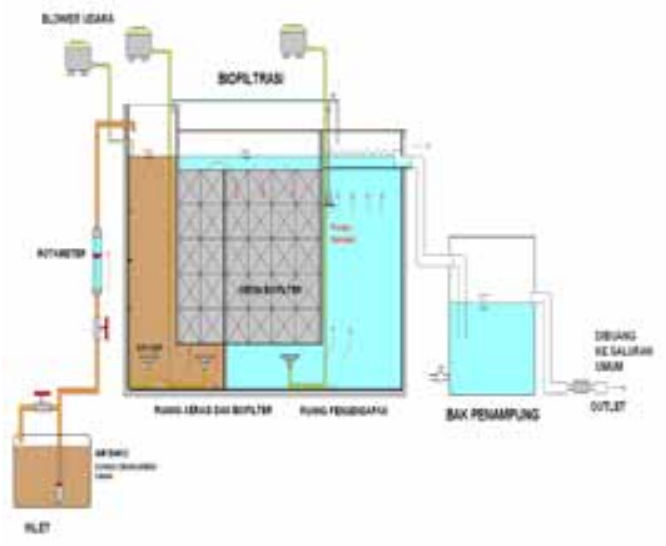

Gambar 3. Skema penelitian biofiltrasi

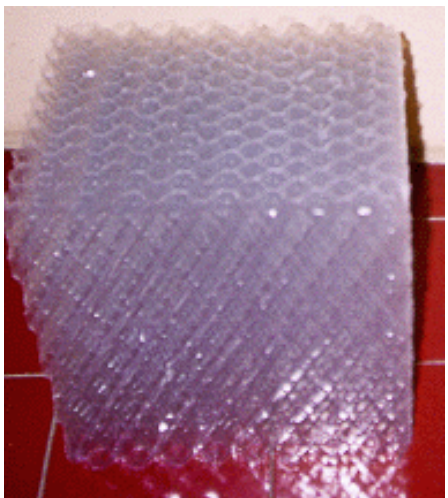

Gambar 4. Media penyangga biofiltrasi type sarang tawon

Sampling dilakukan setiap hari di inlet dan outlet biofiltrasi, Sampel selanjutnya dibawa ke laboratorium kualitas air milik PALYJA untuk dilakukan analisa secara duplo dengan metode analisa parameter sesuai prosedur Standar Nasional Indonesia (SNI). Parameter yang dianalisa adalah $\mathrm{pH}$, TSS, Organik Permanganat, Amonia Nitrogen dan MBAS (deterjen). Data analisa dituangkan dalam bentuk grafik dan tabel serta gambar yang selanjutnya dianalisa secara deskriptif.

\section{HASIL DAN PEMBAHASAN}

Gambar 5 menunjukkan pH inlet dan outlet biofiltrasi pada HRT 6 sampai 0,5 jam. Dari Gambar 5 terlihat bahwa untuk keseluruhan HRT, pH inlet selalu lebih rendah dari $\mathrm{pH}$ outlet. Hal ini terjadi karena di dalam biofiltrasi ada proses pembubuhan udara sehingga $\mathrm{CO}_{2}$ di dalam air akan berkurang yang menyebabkan $\mathrm{pH}$ naik. ${ }^{7}$ Namun demikian $\mathrm{pH}$ air di outlet masih dalam batas netral yakni antara 7 dan 8 .

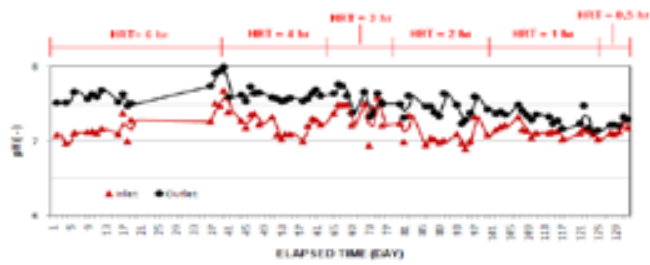

Gambar 5. pH inlet dan outlet biofiltrasi 
Gambar 6 menunjukkan konsentrasi TSS beserta efisiensi penyisihannya. Konsentrasi TSS di air baku berkisar antara 13,5 sampai $275 \mathrm{mg} / \mathrm{l}$. Saat penelitian ini berlangsung, sering terjadi hujan. Air hujan akan membawa sedimen sehingga air sungai keruh. Oleh karena itu berfluktuasinya TSS di air kemungkinan besar dipengaruhi oleh curah hujan di hulu. Pada HRT 6 jam efisiensi pengolahan masih belum stabil dan berfluktuasi, namun kecenderungannya meningkat dari $13-100 \%$. Pada HRT 4 jam sampai dengan 1 jam efisiensi menurun yakni rata-rata $85 \%$ pada HRT 4 jam dan $46 \%$ pada 1 jam. Hal ini disebabkan oleh berkurangnya kemampuan biofilter untuk menahan padatan pada waktu tinggal yang semakin pendek.

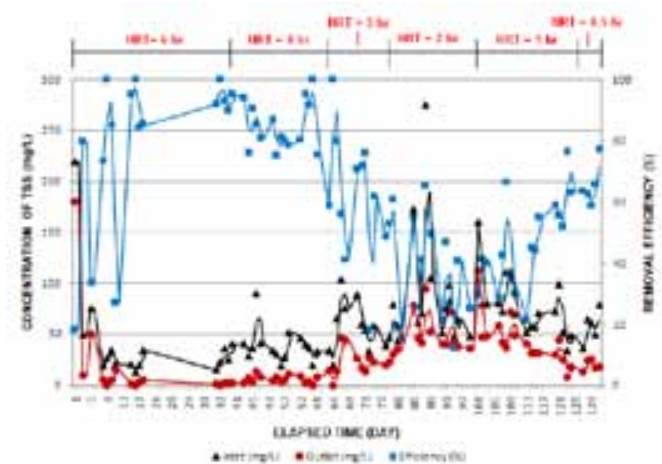

Gambar 6. Konsentrasi TSS berikut efisiensi penyisihannya

Pada pertengahan HRT 1 jam ke 0,5 jam efisiensi TSS cenderung naik. Pada saat itu frekwensi hujan menurun sehingga konsentrasi TSS di air baku ikut menurun. Dengan menurunnya konsentrasi TSS ini menjadikan efisiensi penyisihan TSS meningkat bahkan efisiensi yang dapat dicapai menjadi lebih baik dibanding pada kondisi HRT 1 jam. Pada kondisi HRT 1 jam, konsentrasi TSS hasil olahan rata-rata 43 $\mathrm{mg} / \mathrm{l}$, dan angka ini sudah memenuhi baku mutu sebagai air baku air minum.

Konsentrasi zat organik pada inlet dan outlet biofiltrasi berikut efisiensi penyisihannya ditampilkan pada Gambar
7. Dalam waktu 4 bulan pengamatan, organik permanganat di air baku terendah $8,45 \mathrm{mg} / \mathrm{l}$ dan tertinggi $25,5 \mathrm{mg} / \mathrm{l}$. Pada HRT 6 jam efisiensi berfluktuasi namun kecenderungannya naik yakni pada kisaran $13-48 \%$.

Mekanisme penyisihan organik ini terjadi dengan proses biologis pada lapisan mikroorganisma (biofilm) yang melekat pada dinding media biofiltrasi 11). Saat awal biofiltrasi dioperasikan, mikroorganisme kemungkinan masih sedikit yang menyebabkan efisiensi penyisihan rendah. Sehingga pada HRT 6 jam terjadi kenaikan efisiensi bersamaan dengan berjalannya waktu. Pada waktu tinggal 4 jam sampai dengan waktu tinggal 1 jam efisiensi penyisihan organik kecenderungannya menurun. Dengan demikian semakin singkat HRT, efisiensi semakin mengecil. Pada pertengahan HRT 1 jam sampai 0,5 jam terjadi kecenderungan kenaikan efisiensi.

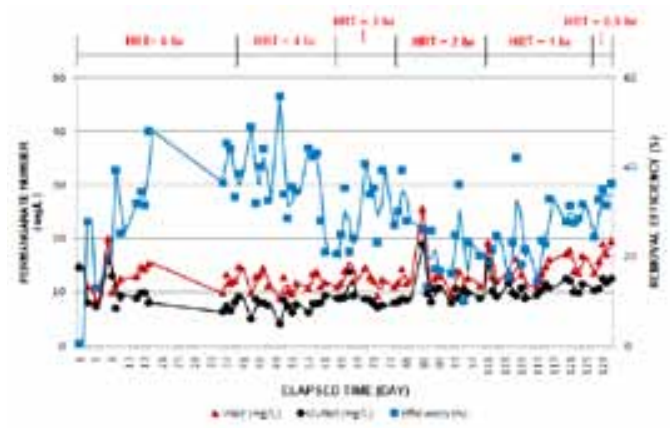

Gambar 7.Konsentrasi organik permanganat berikut efisiensi penyisihannya

Dari data konsentrasi TSS, pada HRT 0,5 jam ternyata TSS lebih rendah dibanding HRT 1 jam. TSS ini akan terakumulasi pada permukaan media sehingga akan menghalangi proses difusi polutan organik. Dengan rendahnya TSS, maka proses difusi akan berjalan lebih baik. Oleh sebab itu pada HRT 0,5 jam, karena akumulasi TSS lebih rendah, efisiensi penyisihan organik semakin baik. Pada HRT 1 jam, konsentrasi organik di outlet biofiltrasi rata-rata adalah 10,7 mg/l.

Gambar 8 menunjukkan konsentrasi 
ammonia nitrogen di air baku, air olahan serta efisiensi penghilangannya. Saat HRT dipersingkat dari 6 jam menjadi 4 jam, kecenderungannya efisiensi menurun dari $90 \%$ menjadi $70 \%$ dan stabil di sekitar $70 \%$ walaupun waktu tinggal di persingkat menjadi 3 dan 2 jam.

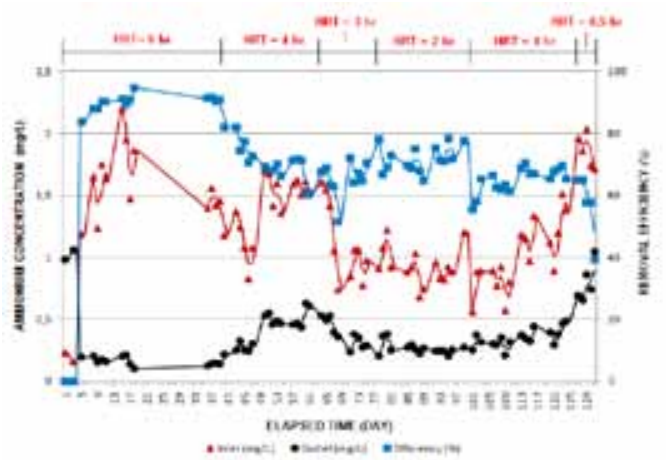

Gambar 8. Konsentrasi amonia nitrogen berikut efisiensi penyisihannya

Penyisihan amonia berlangsung optimum pada $\mathrm{pH} 7,5 .{ }^{12}$ Dari data $\mathrm{pH}$ pada gambar 2, untuk HRT 3 dan 2 jam, $\mathrm{pH}$ outlet 7,5, sementara untuk HRT 4 jam $\mathrm{pH}$ sekitar 7,8. Dengan demikian pengaruh $\mathrm{pH}$ lebih dominan dibanding HRT yang menyebabkan pada HRT 4, 3 dan 2 jam efisiensi penyisihannya hampir sama. Pada HRT 1 jam, pH air lebih rendah yakni sekitar 7,2. Efisensi penyisihannya turun menjadi rata-rata $65 \%$. Penurunan ini disebabkan karena perpendekan HRT dan lebih rendahnya $\mathrm{pH}$. Pada HRT 1 jam ini konsentrasi amonia di air olahan rata-rata $0,34 \mathrm{mg} / \mathrm{l}$.

Amonia nitrogen merupakan polutan dalam air yang dengan adanya organik akan memicu tumbuhnya mikroba dalam air. Oleh karena itu penghilangan amonia nitrogen dalam air dilakukan dengan cara khlorinasi membentuk khloramin. Penurunan kadar amonia dengan khlor memerlukan konsumsi khlor 7 - $11 \mathrm{mg} / \mathrm{l}$ untuk setiap $1 \mathrm{mg} / \mathrm{l}$ amonia nitrogen. Dengan demikian apabila konsumsi khlor tinggi akan berakibat pada sisa khlor di air olahan PAM yang tinggi pula. Dengan tingginya sisa khlor ini bila terdapat zat besi dan mangan terlarut maka sisa khlor tersebut akan mengoksidasi besi dan mangan terlarut sehingga warna air menjadi kuning. ${ }^{12)}$

Hasil analisa air untuk parameter MBAS berikut berikut efisiensi penyisihannya dapat dilihat pada Gambar 9. Kandungan MBAS di air baku berkisar antara 0,05 sampai 0,53 mg/l. Pada HRT 6 jam efisiensi berfluktuasi yakni pada kisaran 29-93\%, Pada HRT 4 jam sampai dengan 3 jam kecenderungannya efisiensi menurun dari rata-rata $69 \%$ pada 4 jam dan $30 \%$ pada 2 jam. Dengan demikian reaksi penyisihan MBAS sangat dipengaruhi oleh HRT. Semakin pendek HRT, semakin kecil efisiensi penyisihannya. Pada HRT 2 jam sampai HRT 1 jam terjadi kecenderungan kenaikan efisiensi, dikarenakan kondisi TSS pada air baku lebih rendah pada HRT 1 jam. Pada HRT 1 jam ini, konsentrasi MBAS ratarata di air hasil olahan biofiltrasi adalah $0,1 \mathrm{mg} / \mathrm{l}$.

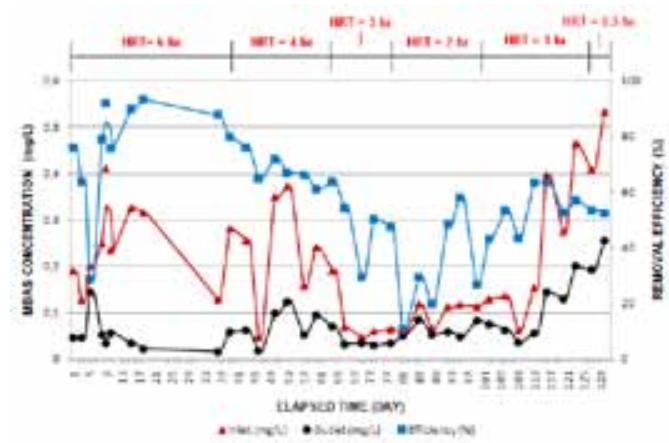

Gambar 9. Konsentrasi MBAS berikut efisiensi penyisihannya.

Hubungan antara konsentrasi TSS di inlet dengan efisiensi penyisihan organik permanganat dan MBAS dapat dilihat pada Gambar 10. Dari gambar terlihat bahwa bila TSS rendah maka efisiensi penyisihan organik dan MBAS naik, demikian pula sebaliknya. Hal ini membuktikan bahwa lumpur TSS yang terakumulasi di dinding media menghambat proses degradasi polutan organik dan MBAS di lapisan biofilm. Dari fenomena ini dapat diketahui bahwa sistem biofiltrasi kurang cocok untuk air dengan TSS yang tinggi. 
Pada akhir dari proses penelitian ini, air yang ada di reaktor biofiltrasi di kosongkan dan diamati kondisi media seperti terlihat pada Gambar 11. Dari gambar terlihat bahwa media biofiltrasi banyak dipenuhi oleh lumpur TSS.

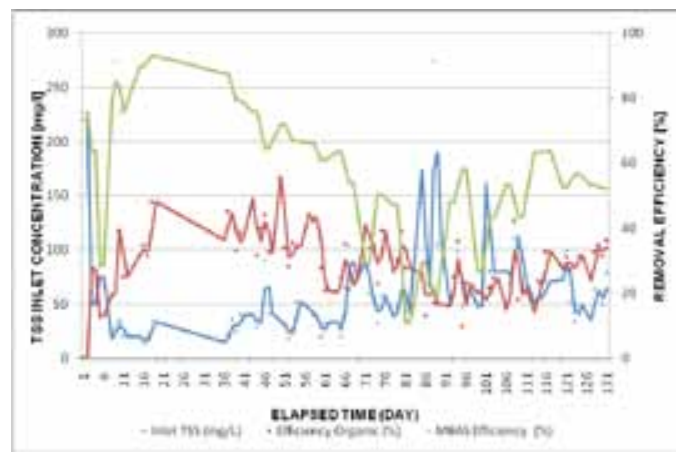

Gambar 10. Hubungan TSS inlet dengan efisiensi penyisihan organik dan MBAS
Tabel 1 menunjukkan rangkuman kualitas air hasil olahan biofiltrasi pada HRT 1 jam. Pada Tabel 1 terlihat bahwa keseluruhan parameter yang diuji yakni $\mathrm{pH}$, TSS, Organik Permanganat, MBAS dan Amonia di air hasil olahan biofiltrasi sudah berada di bawah baku mutu air baku air minum. Artinya, air olahan biofiltrasi dengan HRT 1 jam dapat dimanfaatkan sebagai air baku air minum, khususnya PAM Taman Kota.

\section{KESIMPULAN}

Proses pre-treatment untuk perbaikan kualitas air baku IPA Taman Kota yang memiliki kandungan polutan diantaranya TSS, Organik, Amonia dan MBAS tinggi dapat dilakukan dengan menggunakan reaktor biofiltrasi. Dengan hydraulic retention time (HRT) 1 jam, kualitas air hasil olahan

Tabel 1. Rangkuman kualitas air hasil olahan biofiltrasi pada HRT 1 jam

\begin{tabular}{|c|c|c|}
\hline PARAMETER & NILAI & $\begin{array}{c}\text { BAKU MUTI } \\
\text { (Pergub DKI No 582,1995) }\end{array}$ \\
\hline $\mathrm{pH}$ & 7,2 & $6,5-8,5$ \\
\hline TSS $(\mathrm{mg} / \mathrm{l})$ & 42,8 & 100 \\
\hline $\begin{array}{c}\text { ORGANIK PERMANGANAT } \\
(\mathrm{mg} / \mathrm{l})\end{array}$ & 10,7 & 15 \\
\hline MBAS $(\mathrm{mg} / \mathrm{l})$ & 0,1 & 1 \\
\hline AMONIA NITROGEN $(\mathrm{mg} / \mathrm{l})$ & 0,34 & 1 \\
\hline
\end{tabular}

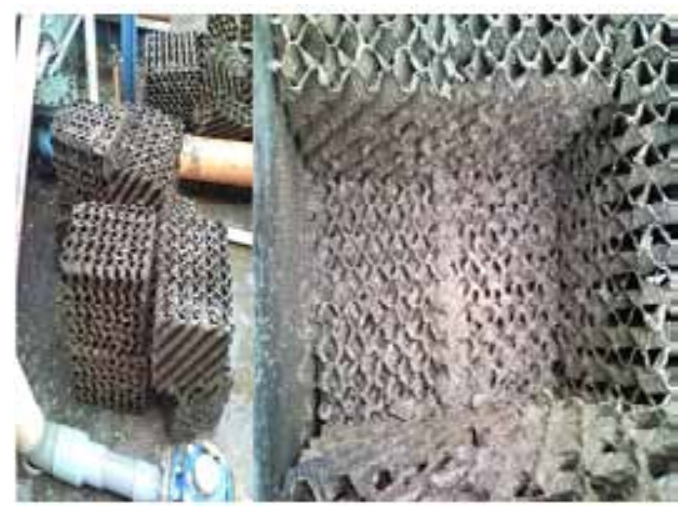

Gambar 11. Media biofiltrasi setelah digunakan selama 4 bulan biofiltrasi dapat mencapai baku mutu air baku air minum golongan B dalam SK Gub DKI No. 582 tahun 1995. Dengan demikian, air setelah di pre-treatment dengan biofiltrasi ini diharapkan dapat diolah dengan Instalasi Pengolahan Air (IPA) yang ada saat ini untuk menghasilkan kualitas air olahan yang memenuhi standard kualitas air minum.

Tingginya TSS akan menurunkan efisiensi penyisihan polutan pada sistem biofiltrasi. Oleh karena itu disarankan sebelum proses biofiltrasi perlu dilakukan proses pengendapan awal (pre-treatment) dengan waktu yang cukup agar supaya TSS 
tidak menyumbat di media isian biofiltrasi.

Guna mendapatkan data yang dapat dipakai sebagai dasar disain IPA skala besar, disarankan untuk dilakukan penelitian serupa pada periode musim kemarau. Pada periode musim kemarau ini konsentrasi polutan dalam air baku kecenderungannya lebih tinggi sehingga hasil yang diperoleh kemungkinan berbeda.

\section{UCAPAN TERIMAKASIH}

Terimakasih disampaikan kepada menejemen PT. PALYJA yang telah memberikan kepercayaan serta dana untuk penelitian perbaikan kualitas air baku IPA Taman Kota, Pesing, Jakarta Barat.

\section{DAFTAR PUSTAKA}

1. Tody Ferdica. 2007. Pengaruh Variasi Waktu Tinggal Pada Kombinasi Biofilter dan Ultrafiltrasi Dalam Pengolahan Air Minum dengan Parameter Amoniak, Nitrat, Nitrit dan Deterjen. Skripsi Jurusan Teknik Lingkungan, Jakarta: Universitas Trisakti.

2. Keputusan Gubernur Kepala Daerah Khusus Ibukota Jakarta Nomor 582 Tahun 1995. Tentang Penetapan Peruntukan Dan Baku Mutu Air Sungai atau Badan Air Serta Baku Limbah Cair Di Wilayah Daerah Khusus Ibukota Jakarta.

3. Garno, Y.S. 1998. Dampak Limbah Deterjen Terhadap Kualitas Dan Organisme Air. Jurnal Teknologi Lingkungan Volume 1No.1.
4. Sawyer,C.N \& P.L. McCarty. 1967. Detergents, Chemistry For Sanitary Engineers. Second Edition McGraw-Hill Book Company Tokyo.

5. Ainsworth, S.J. 1996. Soaps and Detergent. Chem. Eng. News.

6. Horan, N.J.1990. Biological Wastewater Treatment Systems, Theory and Operate. University of Leeds, England. John Wiley \& Sons Ltd.

7. Metclaf And Eddy. 1991. Waste Water Engineering. Mc Graw Hill.

8. Grady, C.P.L and Lim, H.C.1980. Biological Wastewater Treatment. Marcel Dekker Inc. New York.

9. Verstraete, W., and E. Van Vaerenbergh. 1972. Heterotrophic Nitrification By Arthrobacter Sp. Journal Bacteriology.110:955-961.

10. Tatsumi Iwao. 1971. Water Work Engineering (JOSUI KOGAKU). Tokyo: JapaneseEdition.

11. Tove A Larsen and Poul Harremoës. 2003. Degradation mechanisms of colloidal organic matter in biofilm reactors. Department of Environmental Engineering, BIdg 115, Technical University of Denmark, DK-2800, Lyngby, Denmark.

12. Keen G.A. and J.I. Prosser. 1987. Interrelationship between $\mathrm{pH}$ and growth of Nitrobacter. Department of Genetics and Microbiology, Marischal College, University of Aberdeen,Scotland. 